Rok XV (2020) | 1 (29)| S. 229-249

https://doi.org/10.12797/LV.15.2020.29.15

\begin{abstract}
Adam Fałowski (1)
Uniwersytet Jagielloński, Kraków

adam.falowski@uj.edu.pl

Wiktoria Hojsak (D)

Uniwersytet Jagielloński, Kraków

wiktoria.hojsak@uj.edu.pl
\end{abstract}

\title{
Z ETYMOLOGII ŁEMKOWSKICH. CZ. V ${ }^{1}$
}

Słowa klucze: etymologia, leksyka łemkowska

Keywords: etymology, Lemko vocabulary

\section{Ластівниця}

Udokumentowane leksykograficznie przez J. Riegera, por. łastiwnycia 'otwór (okienko) w szczycie chałupy’, łastiwnyk, hłastiwnyk (R), R. Bronikowską, por. łastiwnyk 'otwór w szczycie chałupy (na strychu)' (Br) oraz J. Horoszczaka, por. ластивниия 'małe okienko u szczytu „хыжы”' (H). R. Bronikowska cytuje wyjaśnienie informatora, skąd się wzięła taka nazwa: „na totu dźuru litauxy łastiuxkы i na podi mauxy hńiz-

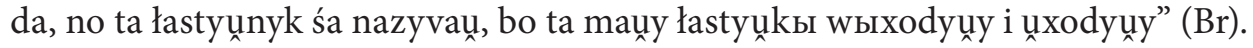

W gwarach zakarpackich wyraz notował już I. Werchratski: ластовица 'Schwalbe', „ластовица бывать на хыжи” (WUZ).

- Derywat sufiksalny od łemk. ластивка, ластівка 'jaskółka'. Co do znaczenia por. pol. jaskółka 'okno wystające z połaci dachu, przykryte własnym daszkiem’ (SB).

1 Cz. I zob. „LingVaria” 2018, nr 1 (25), s. 125-139, cz. II zob. „LingVaria” 2018, nr 2 (26), s. 221-239, cz. III zob. „LingVaria” 2019, nr 1 (27), s. 261-277, cz. IV zob. „LingVaria” 2019, nr 2 (28), s. 211-227. Wkład współautorów jest równy i wynosi po 50\%. 


\section{Люштати}

Pojawia się w niektórych źródłach łemkowskich, poczynając od słownika I. Werchratskiego, zwykle w postaci prefiksalnej, por. полюштати 'mit flüssigen Koth besudeln', коньі ся нам полюштали (W), полюштати 'ubłocić się' (H), люштаmи 'мочити росою, забруднювати болотом (одяг, взуття)', люштатися 'ідучи, забризкуватися водою, росою, забруднюватися болотом', злюштати 'заляпати, замочити росою, болотом', злюштатися 'ідучи, заляпатися водою, росою, болотом', полюштатися 'те саме, що злюштатися' (Т).

Słownik I. Hrinczenki podaje za I. Werchratskim: полюштатися ‘забрызгаться жидкой грязью' (Hrincz III: 291).

Paralelne formy spotykamy w gwarach słowackich, por. słc. dial. luštat' (sa) 'máčat', rosit' (napr. spodok šiat)', lušta, mokri jag lužda 'vel'mi mokry, premočený (o človeku)' (SSN II: 99).

- ESUM (IV: 506): „неясне; можливо, афективне утворення”. Zapewne rozwinęło się z postaci ${ }^{\star}($ по)хлюштати, por. np. ukr. хлющати розм. 'сильно йти, лити (перев. про дощ); текти, стікати з кого-, чого-небудь; бути дуже мокрим, перенасиченим вологою', хлющ, хлюща 'сильний дощ; злива' (WTSSUM: 1347), pol. pochlustać 'pooblewać, pobryzgać, ochlapać' (SW IV: 299), słc. dial. chlušt' expr. 'daživé počasie, nečas', mokri jak chlujśčc vel'mi premočený' (SSN I: 666). Ps. *xlustati /

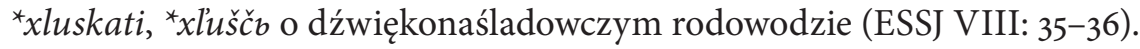

\section{Лябати}

Sporadycznie trafia do słowniczków łemkowskich, por. лябати 'pić po kociemu, chlipiąc językiem po trochę' (H), лябати 'хлептати, підбираючи рідину язиком (про кота, пса)' (Т), a także ze względu na identyczne znaczenie либати 'пити молоко або воду (про кота)' (Р1), лыбати 'хлебтати, хлиськати молоко або воду (про кота)' (Р).

Występuje w gwarach polskich: labać 'pić dużo' (z okolic Nowego Sącza - SW II: 669), olabać się 'opić się' (SW III: 763), zlabać się 'ts.' (SW VIII: 516) i słowackich: labat' 1. expr. 'nemierne pit'. 2. 'silno pršat', liat' (SSN II: 7). Znane też w czes., por. lábati 'píti velkými doušky', dial. chlabát 'píti (o psu apod.)' i sch., por. labati 'chłeptać, nieprzyzwoicie jeść, pić' (Machek: 316; SESł IV: 17).

- ESSJ (XIV: 6) widzi tu ps. twór ekspresywny o podłożu dźwiękonaśladowczym *labati powiązany z ${ }^{\star}$ lapati. F. Sławski opowiada się za pożyczką z niemieckiego, por. niem. dial. labben, lappen 'lizać, chłeptać, żłopać, dużo jeść i pić, hulać' (SESł IV: 17).

W okolicach Nowego Sącza można się zetknąć z formą na le-: lebać 'ts.', a także rzeczownikiem lopy 'niesmaczny napój' (pozyskane od śp. Janiny Fularz). Forma czasownikowa przypomina ros. хлебать 'есть, черпая ложкою, жидкое; отпить 
глотками через край', brus. dial. хлябаць 'есть' < ps. *xlebati (ESSJ VIII: 25), forma rzeczownikowa nawiązuje m.in. do czes. chlopati 'хлебать' (ibid.: 36), słc. dial. chlopat 'hltavo a hlučne žrat al. pit' (SSN I: 664). Obie przemawiają raczej na korzyść pierwszego rozwiązania (ps. $\left.{ }^{*} l a b-/{ }^{*} l a p-;{ }^{*} x l a b-/{ }^{*} x l a p-;{ }^{*} x l e b-/{ }^{*} x l e p-;{ }^{*} x l o p-\right)$.

\section{Лябдати, лябздати}

Stosunkowo nieźle umocowane w leksykografii, por. лябдати 'plappern', жена, што лябдже, лябда 'Plauderei, Plapperei; Klatscherei; Fabel, dummes Geschwätz', лябды або плеткы 'плетеницї, паплянина' (WU), лябздати 'казати щось недоречне' (В-Н; АР), лябдати знев. 'плести небилиці, говорити нісенітниці' (Р1; Р), лябзда 'nieprzyzwoite powiedzonko lub ktoś je opowiadający, albo chlapiący językiem byle со', лябздати 'mówić coś nieprzyzwoitego lub byle co', лябздуля 'plotkarka, pleciuga' (Н), лябзда 'базіка', лябздати 'базікати' (Т), ляйбздати 'казати щось не до речі - mówić coś niedorzecznego (głupoty)' (Wys).

Słownik B. Hrinczenki przytacza лябдати 'болтать' z lokalizacją Угорщина (Hrincz II: 39o). Por. też ESUM (III: 333). Najbliższe formalnie i znaczeniowo słc. dial. l'abdat' i l'aptat' (labdžec, l'abzdac, l'abdat') 1. expr. 'zbavovat' sa výlučkov, lajnit'. 2. expr. 'nezmyselne hovorit', tárat'. 3. expr. 'klebetit', ohovárat', l'abda i lapta (l’abdža, labzda, labza) 1. expr. 'mokrý riedky hnoj'. 2. expr. 'zle pripravené nechutné jedlo'. 3. expr. 'klebeta, ohováranie, pletka'. 4. pejor. 'nadávka neporiadnej, naničhodnej, klebetnej žene' (SSN II: 7-8), w gwarach polskich tylko wariant z bezdźwięczną spółgłoską wargową, por. laptać 1. 'mówić nieprzyzwoicie, gm. chlapać ozorem'. 2. 'trawić na rzadko (o krowie)', laptoń 'papla, mówiący bez namysłu', laptula 'plotkarka' (SW II: 685).

- ESUM (III: 333) uznaje лябдати za afektywną formację o pochodzeniu onomatopeicznym, łącząc ją m.in. z dość niejasnym ros. dial. лябзить 'базікати, бурмотіти', лабзать 'розголошувати таємницю, базікати', лябзять 'тс.' oraz całkowicie niezasadnie z pol. dial. labiedzić, labodzić, labodzieć, lebodzieć 'нарікати, скаржитися, лементувати; бідувати'. Rzeczywiście dźwiękonaśladowczy charakter wyrazu nie wzbudza zastrzeżeń, natomiast rozwój jego znaczenia przebiegał najpewniej w sposób następujący: 'wydalać rzadki kał (o krowie)' > 'mówić, używając słów niecenzuralnych' > 'plotkować. Podobną sytuację obserwujemy w przypadku łemk. хляпати 'chlapać' і ляпати 'plotkować lub pleść byle со', ляпа 'plotka, plotkarka' (H; Bar), ляпа 'Klatschmaul, Plappermaul' (WZ), хляпати 1. 'бризкати рідиною; розхлюпувати щось; ляскати по воді'. 2. 'падати, лити (про дощ)'. 3. знев. 'ляпати, говорити щось нерозумне, недоречне' і ляпати 1. 'капати, падати краплями; ляпати, ронити краплі на що-небудь'. 2. перен. 'оббріхувати, наговорювати на когось' (Р). Postać лябздати powstała w rezultacie kontaminacji (na gruncie słowackim): labdat' + bzdiet', por. słc. dial. bzdiet' i bziet' pejor. 'puštat vetry, smradit' 
(SSN I: 192), pol. dial. bździeć, bździć2, łemk. бзвдзimu (Wys), por. też łemk. skontaminowane хвалибзда 'chwalipięta' (H).

\section{Лянкорити ся}

Zanotował wyłącznie J. Horoszczak: лянкорити ся 'zamartwiać się, smucić się' (H).

W języku polskim: rankor, dial. jankor, jankur, jankórka, inkurka, lankor, ankor, ankur, ankurka, hankur 1. 'złość, zawiść, zawziętość, nienawiść, chrapka, gniew, uraza, żal do kogo, niesnaska, nieporozumienie'. 2. 'zmartwienie, smutek, zgryzota, frasunek, żal' (SW V: 475; SEBr: 453), jankor, lankor 'smutek, złość, żal, zmartwienie' Śl, Mp, Wp (MSGP: 89).

- Zapożyczenie z języka polskiego, gdzie z łac. rancor 1. 'zgnilizna, stęchlizna'. 2. 'zadawniona wrogość, mściwość, zajadłość, zawziętość'.

\section{Маляґа}

$\mathrm{Z}$ wyrazem tym stykamy się już w słowniku I. Werchratskiego, por. мaляsa 'langsame Weibsperson; langsamer Patron' „што робыт помалы” (W), a następnie u P. Pyrteja: маляsа 'повільна людина' (Р1) і J. Horoszczaka: маляsa 'ten, kto pomału pracuje' $(\mathrm{H})$.

- Być może należy wiązać z buk. малягати, маляsати 'невміло, неоковирно писати'; маляцати, малацкати 'невміло фарбувати, мазати' (SBH), со ESUM (III: 374) uznaje za „афективне утворення, пов’язане з малювати”. Czynność malowania utożsamiano z pracą powolną, o czym może świadczyć znaczenie czasownika малювати w ukraińskich gwarach zachodniopoleskich: малювати перен. 'старанно виконувати якусь роботу, увесь час приглядаючись, приміряючи й оцінюючи їi’ (A). Nie można też wykluczyć, że mamy do czynienia z derywatem od łemk. nомаль 'pomału, powoli' (H).

\section{Маранча}

Ten zagadkowy wyraz znajduje się zarówno w słowniku I. Werchratskiego: маранча 'grosse Menge', велька того маранча 'das ist grosser Menge', маранча гусении на каnусті 'eine Grosse Menge von Raupen am Gartenkohl' (W), jak też w dwóch nowszych pozycjach leksykograficznych, por. маранча 'велика кількість', маранча гусаниц на капусті ( $\mathrm{P} 1)$, маранча 'mnóstwo, wielka ilość czegoś', маранча гусении, на капусті $(\mathrm{H})$.

2 Podziękowania za pomocne wskazówki należą się dr. Tomaszowi Kurdyle. 
Pojawia się w słowniku B. Hrinczenki wyłącznie jako cytat z I. Werchratskiego: маранча 'множество' (Hrincz II: 405).

- ESUM (III: 389) uznaje za niejasne. Można przyjąć z dużą ostrożnością, że mamy tu do czynienia z kontaminacją łemk. сараньча, шараньча 'велика кількість крилатих комах, що знищує посіви, рослинність' (Р1), por. np. pol. szarańcza 'chmara, ćma, zatrzęsienie czego, ciżba, tłum; tłuszcza, chałastra, hultajstwo' (SW VI: 565-566), 'przenośnie o dużej liczbie czegoś, o tłumie, zwłaszcza o tłumie niszczącym coś; chmara' (SJP III: 394) z łemkowską nazwą mrowiska, por. muriancza kupa 'mrowisko', muriańcza kupa, muriacza kupa, murianczana kupa 'ts.' (R), мурянча купа 'ts.' (P; H).

\section{Maceca}

Wyraz słabo zadomowiony w leksykografii łemkowskiej, bowiem oprócz I. Werchratskiego, por. масеса 'langsame, unbehilfliche Weibsperson', жена повільна як смола, dostrzega go jeszcze tylko P. Pyrtej: масеса 'повільна, безпомічна жінка' (P1; P) i J. Horoszczak: мaceca 'kobieta powolna jak smoła', obaj zapewne pod wpływem tego pierwszego.

ESUM (III: 406) także powtarza za I. Werchratskim: dial. масеса 'млява, повільна жінка'.

- Wyłącznie łemkowskie. Niejasne. Godna uwagi paralela występuje w rosyjskich gwarach archangielskich: масоса 'ребенок, который держит пальцы во рту', być może od cocamb 'ssać' (Vasmer II: 578).

\section{Маскати}

Czasownik posiada solidną dokumentację, por. maskaty 'smarować'” „babы maskali z rukami polipyty zemlu” (w chałupie) (R), маскати 'smarować lekko tłuszczem, jajkiem lub wybierać chlebem z talerza resztki sosu, tłuszczu itp.' (Н), маскати 'вибрати дочиста, вилизати' „Маскай тото мися од масла хлібом, бо лишком ся не вибере так дочыста. Юж маскаш тіўко, же зоб’єш помисятко” (PanD), маскаmu 'вибирати дочиста, вилизати' (АР), маскати 'вимазувати, вибирати хлібом і т. ін. залишки жиру чи якоїсь напіврідкої страви' (Т), омаскати (хліб - chleb) '[помастити] зверхи яйцем перед його печенням - przed wypiekiem pomazać z wierzchu (rozbitym) jajkiem' (Wys).

Dokładny odpowiednik znajdujemy w gwarach słowackich, por. maskat' expr. 'tíšit', hladkat', máskat 'vytierat', oblizovat' (SSN II: 126), także muskat' 1. 'upravovat uhládzaním'. 2. 'vytieraním vyberat zvyšky' (ibid.: 222) oraz polskich, por. maskać 'gładzić, muskać' (SW II: 893), daw. mazgać 'prawdopodobnie głaskać, pieścić 
a. łagodzić, usmierzać' (SPXVI 13: 226), dial. mazgać 'mazać, smarować, brudzić', mazgać się 'mazać się, brudzić się, sralis mazgalis 'ni to, ni owo' (KSGP), por. również pol. muskać od XV w. 'dotykać, głaskać, gładzić lekko delikatnie', dial. też 'powlekać, smarować, muzgać 'chlebem albo ziemniakami wycierać resztki tłuszczu, sosu z talerza, miski, patelni' (ESSJ XX: 203; SEBor: 343 ).

- Zapewne należy wywodzić od ps. *mazati 'mazać, smarować, namaszczać' (zob. SEBań II: 155). Ps. ${ }^{\star} m u s k a t i /{ }^{\star} m u z g a t i$ uznawane jest za pierwotne intensivum $\mathrm{z}$ sufiksem -sk-l-zg- od słabo zachowanego pierwiastka ${ }^{*} m u$ - (por. $\left.{ }^{*} m y t i\right)$, odpowiadającego lit. máuti 'przeciągać ręką, gładzić, ciągnąć' (SEBr: 349; ESUM III: 540; ESSJ XX: 197-198).

\section{Мджурити, мдзюрити}

Czasownik o słabej dokumentacji leksykograficznej, por. мджурити, мдзюрити 'mrużyć осzу' (Н), мджурити 'мружити (очі)', мджуритися 'мружитися' (Т).

- Z ps. *mbžuriti (sę) 'mrużyć, zamykać, przymykać (oczy), mrugać (oczyma)', czasownika intensywnego z przyrostkiem -ur- od *mbžati/*mbžiti 'mrużyć, drzemać' (ESUM II: 202; ESBM III: 232; ESSJ XXI: 183-184; SEBor: 341).

\section{Медера}

Znane tylko z zapisu J. Horoszczaka: медера 'woda mocno słodzona miodem, przenośnie „coś o wspaniałym, niespotykanym smaku”” $(\mathrm{H})$.

- Nie do końca jasne. W gwarach zakarpackich występuje czasownik медитu 'медом заправляти', паленка межена (für меджена) = горівка медом заправлена (WUZ). Podobnie w gwarach słowackich, por. medit' 'natierat' medom' (SSN II: 143). Brak jednak rzeczownika. Być może łemk. медера jest derywatem od med- + sufiks -era. I. Werchratski podaje jeszcze trzy rzeczowniki z tym sufiksem: uydepa 'Wunderweib (auch Wundermensch, Wunder, ling. gen. masc.)', бамбера 'kugelige Blase; Beer' oraz мушера gew. collect. 'Pflanzenläuse' (W: 97). W nowszych słownikach: чудара, чудера 'coś cudownego lub cudacznego' (H), чудеро 'щось велике, неоковирне' (T). Znane gwarom łemkowskim są też derywaty przymiotnikowy i przy-

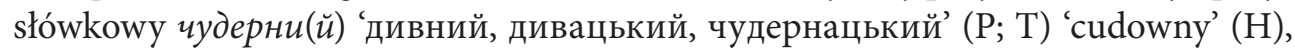
чудерні 'чудернацько' (Т), 'cudownie' (H). 


\section{Металец}

Termin mitologiczny przywołany po raz pierwszy przez I. Werchratskiego, por. металеи 'ein fabelhaftes Schlangentier, Drachen. Dem Volksglauben nach steckt das Unthier seinen Schweif in den Mund und rennt auf diese Weise wie ein Rad rollend umher; auch pfeift es, wenn Regenwetter bevorsteht', „гад, што заложит хвіст до пыска і летит (розумій: біжит, lauft) як качульце, так ся качат і на дойч свище" (W), po latach powtórzony przez J. Horoszczaka, por. металеu 'wąż, który według dawnych wierzeń, brał ogon do pyska i tworząc koło toczył się po zboczu. Gwizdał też podobno na deszcz. Racjonalnie nazwę tę daje się uzasadnić sposobem poruszania niektórych węży' $(\mathrm{H})$.

W słowniku B. Hrinczenki przytoczono za I. Werchratskim (Hrincz II: 419). Zob. także ESUM (III: 447).

- Według ESSJ (XVIII: 110) kontynuuje ps. ${ }^{*}$ metalscb, pochodne albo od ${ }^{*}$ metalb (z sufiksem - $b c b$ ) 'ten, kto rzuca (miota) coś', albo bezpośrednio od *metati 'rzucać, ciskać' (z sufiksem złożonym -locb), por. łemk. metaty 'rzucać' (R; Horb; T; PanD i in.), метатися 'кидатися, перекидуватися' (PanD; P1), 'кидати один і одного чим-небудь' (Т), 'rzucać się' (Tr) i in. Być może ten, który ся мечe, czyli 'miota się, turla się'. Por. podobny łemkowski derywat sufiksalny nадалец na określenie innego gada.

\section{Микытаня}

Zapisane wyłącznie przez J. Horoszczaka: микытаня 'rodzaj wierzchniego, długiego do kolan zimowego okrycia męskiego z białego sukna. W odróżnieniu od чугы była bardziej dopasowana i z rękawami do użytku' $(\mathrm{H})$.

- Być może pochodzi od antroponimu Muкbıma poprzez dodanie częstego w gwarach łemkowskich sufiksu -аня, por. чуга - чуганя. Notowanie wyrazu tylko przez jedno źródło pozwala przypuszczać, że pierwotnie jakiś konkretny Muкbıma miał (lub szył) takie wierzchnie okrycie, po czym mamy do czynienia z rozszerzeniem znaczenia na pewny typ ubrania w ogóle, ale na jakimś ograniczonym terenie.

\section{M(ת)103ґ́pa}

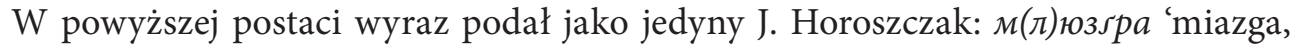
żywa część pod korą drzewa' (H). Podobnie: mizgra 'miazga drzewa' (L), miazgra 'miazga drzewa' (R-Z). W innych źródłach łemkowskich notujemy: мюзsa '?' (WZ), мн'азsа 'підкорове личко дерева' (Horb), miuzga 'miazga drzewa', mniozga, м’язsa 1. 'вичавки, заболонь'. 2. 'м’яка подрібнена плодоовочева маса' (Р). Tu też 
zaliczymy odnotowany w słowniku I. Werchratskiego przymiotnik мязsрятыци, мязгратый 'saftig; fleischig' „оболона поверх бамбуха мязграта” (W).

Wśród licznych dialektalnych form przytoczonych przez ESUM (III: 547), takich jak nр. м’язга, м'яска, мізка, мізька, міска, brak formy zbliżonej fonetycznie do postaci wyrazu hasłowego. Bliżej niż ukraińskie stoją gwarowe postaci słowackie, por. miazga (miezga, mízga, miadzga, mlazga, mliezga, mlazgra, mliezgra); hnízga 1. 'štava prúdiaca v rastlinných cievach'. 2. 'uschnutá rastlinná štava na kôre stromov, živica'. 3. zried. 'člapkanica, blato'. 4. garb. 'odpad pri spracúvaní kože' (SSN II: 159).

- Z ps. *mězga 'sok roślinny, gęsty sok drzewny' > 'rozgnieciona, puszczająca soki masa roślinna', derywat z przyrostkiem -ga od pie. *meigh - 'puszczać wodę, oddawać mocz; ciec' (ESUM III: 547; SEBań II: 173; SEBor: 322; Králik: 357-358; Mańczak: 112). Wśród zgromadzonych przez ESSJ (XVIII: 223-225) licznych przykładów $\mathrm{z}$ całego obszaru słowiańskiego brak postaci z $-u$-. Najbardziej różnorodny materiał pochodzi z języka słowackiego, w tym liczne gwarowe formy z -l-, np. mliazga, mlazga, mliadzga, mladzga, mlazgra. Co do epentezy po nagłosowym $m$ - w słowackim, por. też mliagat' expr. 'miagat', mliaždit' 'drvit', rozpúčat', gniavit' zamiast starszego miaždit' 'hniest' niečo’ (Králik: 363).

\section{Молиґати}

Znane wyłącznie z zapisu J. Horoszczaka: молиsатu 'dopominać się czegoś namolnie, prosić dłuższy czas' $(\mathrm{H})$.

Odpowiada co do formy i znaczenia słc. dial. modlikat' expr. 'úpenlivo prosit' (SSN II: 183).

- Z ps. ${ }^{*}$ modliti 'prosić, błagać, z rozszerzeniem o ekspresywny sufiks $-g(k) a-$, ze wschodniosłowiańskim uproszczeniem grupy $d l>l$. Por. także słc. prosikat' od prosit (Králik: 365).

\section{Mocyp}

Występuje w kilku źródłach łemkowskich: mosur 'człowiek zły, ponury', zmosurenblj (R), мосур 'człowiek ponury (w domyśle zły)', мосурити ся 'chmurzyć się' (H), мосур 'похмура, понура людина' (T), mosur 'ponury człowiek' (Br).

Paralelne formacje znajdujemy w gwarach słowackich, por. mosur 'mrzutý, zamračený človek', mosúrit' sa 'mrzuto sa tvárit', hnevat' sa, mračit sa' (SSN II: 192).

- Nie całkiem jasne. L. Králik widzi tu albo rezultat metatezy hipotetycznej formy *morúsit sa od *morús 'mrzutý, nevrlý človek' (por. czes. morous ekspr. 'zrzęda, tetryk, gderacz, mantyka'), a to z łac. mōrōsus 'niesforny, knąbrny, uparty; posępny, drażliwy' (por. słc. morózny 'mrzutý, neprivetivý, nevlúdny'), albo też powiązanie 
z dial. mosor i mosúr 1 . 'hrča v dreve (na zraste záseku al. zárezu)'. 2. 'nádoba z dutého stromu al. zo stromovej kôry'. 3. 'zatvrdnutá čast' jazvy, zhrubnutá odtlačená pokožka na ruke al. nohe, mozol, otlak' (SSN II: 191-192), co z niem. Maser 'flader, słój (w drzewie)' z rozwojem znaczenia: 'mający na twarzy mosúr, czyli stwardniałą szorstką skórę' > 'posępny, pochmurny' (Králik: 370).

\section{Мотлочыти}

W takiej postaci ( $\left.\mathrm{z}-\check{c}_{-}\right)$notują: I. Werchratski, por. мотўочити 'verb. trans. in der Bedeutung: bedrängen, niederschlagen. тхыр мотўочит куры cf. hal. мотлош Gedränge, Pöbel pol. motłoch' (WU) i J. Horoszczak: мотлочыти 'gnieść, tłamsić' $(\mathrm{H})$. W innych słownikach w nieco odmiennym wariancie fonetycznym $\left(\mathrm{z}-\check{s}_{-}\right)$i nieco odmiennym znaczeniu: мотлошиня 'вовтузіння, невиправдана боротьба, тяганина', мотлошитися 'вовтузитися, боротися' (P1), мотлошыня 'вовтузіння, тяганина'; мотлошытися 'вовтузитися, борюкатися' (Р).

Tu także zaliczymy huc. мотлотити (си) 'бити(ся)' (НH), motyczyty sy 'potykać się, walczyć' (J), ukr. мотлошити розм. 1. 'рвати, ламати, трощити’. 2. перен. 'сильно бити когось' (WTSSUM: 542; ESUM III: 521), słc. dial. motlošit' sa expr. 'tratit' sa' (SSN II: 194), pol. motłoszyć 'szamotać, tarmosić, szarpać, dusić, gnieść' (SW II: 1050).

- Z ps. ${ }^{*}$ motżlošiti (sę), pochodnego od ${ }^{*}$ motżloxz, związanego z pierwiastkiem ${ }^{*}$ met- $\left({ }^{*}\right.$ mesti, ${ }^{*}$ metati) $/{ }^{*}$ mot- $\left({ }^{*}\right.$ motati) (ESSJ XX: 76$)$. Postać $\mathrm{z}-\check{c}$ - powstała zapewne $\mathrm{w}$ wyniku kontaminacji z łemk. czasownikiem mолочыти 'tratować' (H).

\section{Муцикы}

W słownikach łemkowskich niejednolite co do znaczenia, por. муцикы 'волоси зачесані і закручені на висках' (W), múcyky 'pejsy u dziewcząt (od ucha do oka)' (Fal), муциккы 'rodzaj uczesania' (H) oraz муцикы 'бакенбарди' (P1; P). Nieco inną fonetycznie i znaczeniowo formę zanotował I. Werchratski w gwarze Zamieszańców: мущзкы 'грива, што спадат на чеўо коневи - мущкы і у жены' (WZ).

W dialekcie bojkowskim муцик ma dwa znaczenia: 1. 'залицяльник'. 2. 'гладка мала, але сильна людина' (O). W słowniku B. Hrinczenki: муцики мн. 'волоса, зачесанные и завитые на висках' zacytowano za I. Werchratskim (Hrincz II: 457). ESUM (III: 543) osobno rozpatruje ukr. dial. муи 'малорослий кінь; мопс; товстий хлопець; товстий кінь; гладка мала, але сильна людина; здоровий, дужий чоловік', муцик 'маленький собака, мопс', osobno zaś муцики 'волосся, зачесане і закручене на скронях', муиик 'залицяльник'. W polszczyźnie występuje zarówno $m u c$, jak też $m u c y k$, ale wśród kilku znaczeń tego wyrazu brak jest znaczenia 'włosy; bokobrody'. 
- ESUM uznaje wyraz za nie całkiem jasny. Dopatruje się w nim efektu kontaminacji ukr. dial. мушки 'вид зачіски' (z pol. mиszczki 'тс.', a tam z fr. mouche 'муха; цяточка (на обличчі)' oraz муи 'щось мале' (z pol. muc, niem. Mutz 'тварина з обрізаним хвостом, куца тварина' (ibid.: 543-544). Nie można wykluczyć, że jakiś udział w powstaniu etymologizowanego wyrazu miało także ukr. dial. $\boldsymbol{м i -}$ цики 'коротенька вовна з ягнят', będące zapożyczeniem z języka rumuńskiego, por. rum. miță 1. hod. 'pierwsze runo'. 2. 'kosmyk (wełny); kępka (sierści)' (ibid.: 469; WSRP: 519).

\section{Нарабяти}

Znane tylko z jednego źródła łemkowskiego, por. нарабятu 'manipulować czymś zręcznie, z wprawą przez dłuższy czas (głównie chodzi o jakieś narzędzie)' (H).

Obecne w dialekcie bojkowskim: нараб'яти 1. 'працювати'. 2. 'робити комусь зло' (O), języku słowackim: narábat' (narobiac) 'použivat nieco pri nejakej činnosti; zaobchádzat', manipulovat' s niečim, niekým' (KSSJ: 221; SSN II: 338) i polskim: daw. narabiać (czymś) 'posługiwać się, np. „umiem narabiać wszelką bronią” (SEBań II: 265), dial. narabiać 'zajmować się czymś, porabiać' Mp (MSGP: 148).

- Durativum od наробити, pol. narobić (czegoś czymś).

\section{Нарубы}

Przysłówek zarejestrowany w większości dostępnych słowniczków łemkowskich, por. нарубы 'навиворіт' (В-H; P1; P; T), на рубы 'na nice', рубы 'nica, lewa strona odzieży' (H), наруби 'навиворіт - na drugą stronę (o odzieży)' (Wys), narbo (sic!) 'lewa strona ubrania' (D).

Obecny w dialekcie bojkowskim: наруби 1. (про одяг) 'навиворіт'. 2. 'іншим, зворотним боком' (О), наруби, навируби 'навиворіт' (Mat), naddniestrzańskim: наруби 'навиворіт (про одяг)' (S), zakarpackim: наруби 'наизнанку, наизворот' (Hrincz II: 517), нарубы 'навиворіт' (Sab), a także w języku słowackim: naruby 'na rubovú stranu, naopak' (KSSJ: 222; Králik: 513), naruby i narub 'na rubovú stranu, naopak, obrátene' (SSN II: 347). Zna go też dawna polszczyzna, por. na ręby 'na nice, na odwrót' (Knapski: na ręby = na wywrót, na nice szatę oblec), regionalne północne, por. dziś kaszub. na rąbë 'na odwrót' (SEBań II: 268) oraz język czeski, por. naruby, narub 'na lewą stronę, na odwrót, na nice' (SCP: 365 ). W gwarach białoruskich: $\mathrm{Ha}$ pубеи 'навыварат', w języku słoweńskim: narôbe 'навыварат, наадварот' (ESBM VII: 246).

- Odnosi się do ps. * ${ }^{*} q b$ b 'brzeg, skraj, krawędź; odcięty kawałek płótna', rzeczownika odczasownikowego od ps. ${ }^{*}$ robiti 'ciąć, siec' czy iteratywnego ${ }^{*}$ rqbati 'roz- 
cinać, ciąć, siec' (SEBor: 511-512). Rozwój znaczeniowy słowackiego rub 'opačná strana' przedstawił L. Králik (s. 513): 'rúbanie' > 'miesto, kde sa rúbalo, kde bolo nieco odseknuté, oddelené ap.' > 'okraj' > 'zadná, opačná strana'.

$\mathrm{W}$ świetle powyższych danych wydaje się możliwe postulowanie ps. dial. płn. ${ }^{\star} n a$ roby 'na lewą stronę, na odwrót, na nice'.

\section{Нахыр}

Podał jedynie J. Horoszczak: нахыр 'jednak, mimo tego („повідали, же прийдут гнеска, а нахыр не пришли”), według innych informatorów znaczy to „w ogóle”” $(\mathrm{H})$.

- Formalnie odpowiada słc. dial. na chír, np. robid' na chír 'z pýchy' (SSN I: 696), ňevidno ju aňi na chir 'vôbec' (Buffa: 103), co z węg. hír 'wiadomość, wieść; sława; reputacja' (ESUM I: 508; Králik: 226). Znaczenie 'w ogóle' rozwinęło się zapewne ze znaczenia 'brak wieści, wzmianki', por. łemk. ани хыру ани слиху (ани щзаду) про кого-що, від кого-що (FSŁH: 241).

\section{Нездобачкы}

Poza słownikiem J. Horoszczaka: нездобачкы 'niespodziewanie' (H) nieznane leksykografii łemkowskiej.

Paralelna formacja funkcjonuje $\mathrm{w}$ gwarach wschodniosłowackich, por. nezdobačky 1. 'neočakávane, nenazdajky, znenazdania'. 2. 'nepozorovane' (SSN II: 431).

- Pożyczka słowacka. Por. słc. nezdoba 'samopaš, lapajstvo, neplecha, nezbeda, pestvo' (KSSJ: 237), co z ps. *neszdoba, będącego albo złożeniem ${ }^{\star} n e+{ }^{*}$ sødoba, albo derywatem wstecznym od ${ }^{\star} n e s z d o b i t i$ (ESSJ XXV: 28). Por. inne przysłówki na -ačky w języku słowackim: ležiačky, poležiačky, slepiačky, poslepiačky, stojačky, postojačky.

\section{Непек}

Znane wyłącznie ze słownika J. Horoszczaka, por. непек 'niebezpieczeństwo' (H).

- Składa się z partykuły przeczącej ${ }^{*} n e-$ oraz pierwiastka ${ }^{*} p e k$ - (ps. ${ }^{*} p e c ̌ a<$ $<{ }^{\star} p e k$-ja 'troska, zmartwienie', od ps. ${ }^{\star} p e k t i$ sę 'troszczyć się, dbać) (SEBor: 427). Por. pol. bezpieczny, bezpieka, opieka. 


\section{Ніверити}

Czasownik zaprezentowany w słowniku I. Werchratskiego, por. нвіверити, нївечити cf. поневіряти „нову гуньку зньівериў на дойджи” (W), powtórzony następnie przez J. Horoszczaka, por. ніверити 'poniewierać, niszczyć, np. odzież (H). Oprócz tego znajduje się w słowniku wsi Tylicz J. Turczyn, por. ниверити 'нівечити, нищити', зниверити 'знівечити, знищити', зниверитися 'понівечитися, знищитися' (Т).

ESUM (IV: 95) cytuje za I. Werchratskim: ніверити 'нівечити', ponadto: зніверіти 'знікчемніти' z J. Żelechowskiego. W gwarach słowackich: niverit zried. 'robit' škodu, ničit', nivočit' (SSN II: 440), ňiver, ňivera 'skaza' (Buffa: 180).

- $\operatorname{ESUM~(IV:~95)~widzi~związek~z~pol.~dial.~niwera,~niwerja,~niweryja~'велика~}$ ганчірка, онуча' о niejasnym pochodzeniu (zob. SW III: 395). Być może mamy tu do czynienia z kontaminacją form łemk. нивечьти, ukr. нівечити, pol. niweсzус́, słc. nivočit’ oraz łemk. поневератися, ukr. поневірятися, pol. poniewierać się, słc. ponevierat'sa.

\section{Нозгри, нозґрі}

W tej postaci (z - g-) cytuje J. Rieger: nozgri 1. 'nozdrza (chrapy) u konia', nizgri 2. nozgri 'zejście się dwu potoków' (R), O. Horbacz: н’iзsp’i, ‘ніздрі, храпи коня’ (Horb), a także J. Horoszczak: нозspu, нозspi 'nozdrza' (H). Por. też: nozgri 'nozdrza' (Br), nizgry 'nozdrza' (L), nizgry 'nozdrza konia' (R-Z), nuzgri pomn. 'nozdry' (Šiš). W innych słownikach łemkowskich tylko postać z - $d$-, por. ноздpь 'Nüster' (W), ноздра 'ніздря' (Р1), ноздрь 'ніздрі' (Т).

W gwarach bojkowskich: нізsря 'зовнішні отвори в носі тварини' (Mat).

W gwarach słowackich występują obie postaci, por. SSN (II: 452): nozdra i nozder (nozgra, nozger) 1. obyč. mn. č. 'nosový otvor'. 2. 'zvierací (horný) pysk; rypák' (SSN II: 452), podobnie: nozdrica (nozgrica) 'čast' uzdy nad nosovými dierkami’, nozdrina (nozgrina) 'vlhká pôda', nozdrit' (nozgric) expr. 'snorit', zňuchávat' (ibid.). Tu zapewne należy też ukr. dial. нозљравий 'хворий на сап; сопливий' (ESUM IV: 109).

- Z ps. *nozdri (ESSJ XXVI: 15-18). Postać z - g- powstała zapewne pod wpływem słowackim, gdzie najprawdopodobniej jest wynikiem oddziaływania słc. dial. ozger 'konský nosný hlien, sopel' (SSN II: 684), vozger 1. 'sopel'. 2. expr. 'soploš' (Buffa: 311), por. też pol. wozgrza 1. 'osoba wozgrzywa, której z nosa ciecze'. 2. patol. 'śluz zgęstniały i wyrodzony, flegma, śluz nosowy, smark', wozgier 1. a. dial. wozgrzywiec 'smarkacz, smark, smarkul'. 2. w lm. 'smarki konia nosatego' (SW VII: 701), a także łemk. возsрi 'смаркотиння’ (Horb). 


\section{Нютер}

Wyraz dobrze znany na Łemkowszczyźnie, por. niuter 'koń wykastrowany połowicznie', wniuter, niuter 'każde zwierzę źle wykastrowane', niuter ma jedno jajce, nuter (też 'mający jądra w brzuchu') (R), нютер 'zwierzę połowicznie lub źle wykastrowane' $(\mathrm{H})$, niuter 'zwierzę z jednym jądrem ( $\mathrm{z}$ wadą wrodzoną albo źle wykastrowane)' (Br).

Dokładny odpowiednik występuje w gwarach bojkowskich: нутер 'самець, у якого одне або два сім'яні ядра знаходяться в черевній порожнині' (Mat) oraz bukowińskich, por. нутер, нютер 'самець (напр. кінь, кабан), у якого одне або обидва сім’яні ядра знаходяться в черевній порожнині, нутрець’ (SBH). ESUM (IV: 120) przytacza ukr. dial. нутер 'жеребець з одним ядром; нутряк', нуmрець 'самець, у якого ядра містяться всередині, а не в мошонці; хворобливий стан такого самця'. Tu także słc. dial. gnuter 'samec vnútrak, najmä žrebec' (SSN I: 499; Buffa: 83), pol. wnętr, wnęter 'człowiek, samiec, mający jedno jądro w mosznie, a drugie skryte w brzuchu' (SW VII: 666).

- Od ps. wyrażeń przyimkowych *von qtro 'do wnętrza', ‘vøn qtri 'we wnętrzu' (ibid.; SEBor: 705).

\section{Обатурити ся}

Czasownik posiada bogatą dokumentację w leksykografii łemkowskiej, por. oбamoрити ся, обатурити ся = до себе прийти, опамятати ся ' $z u$ sich kommen, zur Besinnung kommen; die Gesunheit wieder erlangen' (W), обатурити(сья) 1. 'прокинутися'. 2. 'прийти до пам'яті' (B-H), обаторитися, обатуритися 'прийти до себе, прокинутись, розбудитись', także пробатуритися 'розбудитися, прокинутися' (Р1), обатуритися знев. 'прийти до тями, прокинутися, збудитися', пробатуритися 'прокинутися' (Р), обатуритися 'опритомніти, виздоровіти' (PanD), обатуритися 'проснутися, прийти до свідомості - zbudzić się, odzyskać świadomość' (Wys), oбamypumu cя 'obudzić się na dobre, oprzytomnieć. Gdy ktoś się formalnie obudzi, ale jeszcze nic do niego nie dociera, to mówi się, że „іщы ся не обатурил”' (Н), обатурити (сья) 1. 'прийти до пам'яті'. 2. 'прокинутися; прийти до пам'яті'. 3. 'опритомніти, оздоровіти' (АР), обатуритися фам. 'прочуняти; прокинутися, збудитися', пробатурити: п. очі фам., вульг. 'прокинутися, встати після сну' (Т). Znane też z autopsji.

Widoczne jeszcze tylko w gwarach bojkowskich, por. пробатуритися 'схаменутися' (O), oraz na Słowacji, por. bátorit' 'rozprávat zo sna' (SSN I: 101), obátorit' expr. 'priviest' k životu', obátorit' sa 1. 'precitnút' (zo spánku)'. 2. expr. 'nadobudnút' odvahu, osmelit' sa' (SSN II: 462).

- ESUM (IV: 126) uznaje za niejasne, proponując jednocześnie powiązanie z ukr. dial. батура 'батіг', co wydaje się zupełnie nieprawdopodobne. Należy raczej 
poprzeć pomysł I. Werchratskiego, który widział tu podstawę węgierską, por. bátor 'śmiały, odważny'. Wskazuje na to chociażby 2 znaczenie słc. dial. obátorit'sa - zob. wyżej.

\section{0бгартати}

Widoczne w kilku źródłach łemkowskich, por. oбzapmamu 'obsypywać np. ziemniaki w rzędach, ręcznie motyką lub konno płużkiem' (H), a ponadto u O. Horbacza: огартаті//огортаті 'плужкувати плужком; підгортати сапою, сапати' (Horb). Tylko z -ar- podaje S. Pancio: огартати 'плужкувати, підгортати, „огартати компері ходили-зме ўшыткы”' (PanD) oraz K. Domaradz: ohartaty 'przegarniać, np. w piecu' (D). W odmiennej (z - or-) postaci podał P. Pyrtej: огортати 'підгортати, окучувати' (P1), огортати 'підгортати (картоплю)' (P). W innych słownikach mamy czasownik o tymże znaczeniu $\mathrm{z}$ innym prefiksem: niдгapтати 'підсипати землею стебла картоплі' (T), pidhartaty 'rozgarniać węgiel w piecu' (R), pidhartaty, podhartaty 'zgarniać, podgarniać' (Br), pidhartaty 'podgarniać' (Tr), pidhartaty 'podsypywać, podgarniać' (L), znane też z autopsji (Małastów).

U Bojków: обгортатu w tymże znaczeniu z -or-, ale mamy też обгартка, загартка 'будь-яка тимчасова накидка для зігрівання' (Mat).

Koresponduje ściśle ze słc. dial. (Szarysz) ohartac 'ohrňat': „S gracku grule ohartali" (Buffa: 186), hartac 1. 'upravovat' teren motykou'. 2. 'zhrňovat' (ibid.: 89).

- Z ps. ${ }^{*}$ obgzrtati (se) (ESSJ XXVII: 55), składającego się z przedrostka ${ }^{*}$ ob$\mathrm{i}^{*}$ 'gzrtati 'zgarniać, rozgarniać', z polską realizacją sonantu (-ar-), por. pol. dial. ogartać 'ubierać się' (SEBor: 156).

\section{Обтавкати}

Znane zaledwie z dwóch źródeł, por. obtawkaty 'ubić, stłuc': obtawkaty len na olij, obtawkaty zerno (R), обтавкати 'obtłukiwać' (H). Niewątpliwie należą tu także: натовканеи 'мозоль на підошві ноги - odcisk na podeszwie' (Wys), натоўкане̂и' 'підбій-болячка під стопою' (Horb).

W gwarach bojkowskich: обтовкати '(насіння льону) молотити' (O), обтевканий 1. 'пошкоджений, побитий', 2. 'дуже побитий (про людину)', обтевкуваmu, обтевкати 1. 'оббивати, пошкоджувати поверхню або край чого-небудь', 2. 'тільки док. дуже побити' (Mat).

- Z ps. ${ }^{\star}$ obtzlkati (se), co pochodne od ${ }^{\star}$ obtzlkt'i $\left({ }^{*} o b-+{ }^{*}\right.$ tlokt’i) (ESSJ XXX: 225), por. ukr. обтовкти 'обтолочь' (Hrincz III: 20). 


\section{Овантолити ся zob. вантолити}

\section{Оддулити ся zob. дулитися}

\section{Одкырхнути ся}

Znajdujemy nieliczne świadectwa obecności tego czasownika w języku Łemków, por. odkyrchnuty 'odłamać' (R), одкырхнути (ся) 'odkruszyć (się), odłamać (o okruchu od czegoś kruchego)' (H).

- Z ps. ${ }^{*}$ otzkrøxati, ${ }^{\star}$ otøkrøxnoti (se) zbudowanego na podstawie czasownikowej ${ }^{\star}$ otøkrøx-, powiązanej z ${ }^{\star}$ otzkrøšiti (sę), por. pol. odkruszyć (się).

\section{Одпырцяти ся zob. копырдати ся}

\section{Одразити}

Zarejestrowano tylko w słowniku J. Horoszczaka: одразити 'zmienić niemiłe uczucie w ustach po zjedzeniu czegoś nieprzyjemnego, gdy nas mdli po czymś itp.' (H).

- Z ps. ${ }^{\star}$ otraziti (sę). Czasownik z prefiksem ${ }^{\star}$ otz- od ${ }^{\star}$ raziti 'ciąć, siec, zadawać ciosy, uderzać; ostro oddziaływać na zmysły lub na umysł’ (ESSJ XXXVIII: 90-91; SEBor: 511). Co do znaczenia por. pol. „Bobku uwarzyć i w beczkę wlać, stęchlinę odraża (= usuwa)" (SW III: 650).

\section{Одчезнути}

Poza słownikiem J. Horoszczaka nienotowane, por. одчезле, одчезнене 'odszczepione, np. gałąź od pnia u samej nasady', одчезнути 'odszczepić, np. gałąź u nasady' $(\mathrm{H})$.

Dokładny odpowiednik występuje w języku i gwarach słowackich, por. odčesnút expr. 'odlomit, odrazit' (KSSJ: 251), dial. odčesnut' (otšeznut') 'podľžne odlomit,' odštiepit', odčechnut' (oččechnút') 'podľžne odlomit', odštiepit', odčaknút' 'odlomit', odštiepit' (SSN II: 520), otčeznuc 'odčeznut' (Buffa: 194). Por. także pol. daw. (XVI) odczosnać 'oderwać, odłączyć' (SEBań I: 234; SEBań II: 369).

- Z ps. ${ }^{*}$ otzčesnoti, złożenie ${ }^{\star}$ otz- $\mathrm{i}{ }^{*}$ česnoti, perf. do ${ }^{\star}$ česati m.in. płn. 'ciąć, obcinać, obciosywać' (SP II: 172). 


\section{Озниця, вожниця, возниця}

Odnotował już I. Werchratski, por. озниця 'Rauchloch' ‘в повалї курної хижи дїра, котрою виходить дим' (W), ўозниця 'дїра в повалї, куди виходить дим' (WZ), a następnie F. Kokowski: возниця 'віконце на дах у курній хаті' (Kok), J. Rieger: oznycia 'otwór, przez który wychodził dym (w kurnej chacie)', woznycia, woźnica 'otwór w suficie z zasuwą na dym (w kurnej chacie)' (R), P. Pyrtej: озниияя 'димохід в курній хаті' (P1), озниия 'комин у курній хаті' (P) i J. Horoszczak: озниця, вожниия 'otwór w suficie w kurnej chacie, przez który uchodził dym (zamykany)', вожниия, возниия 'otwór w suficie kurnej chaty, przez który uchodził dym (był zakrywany)' (H) oraz inni: oznycia, woznycia 'ts.' (Br), woznycia 'ts.' (L), oznyća, woznyća 'ts.' (R-Z).

$\mathrm{W}$ nieco innym znaczeniu występuje $\mathrm{w}$ gwarach huculskich, por. возница (вазниия, озниця) 'приміщення для сушіння фруктів і копчення м'яса' (HH), oznyci(a) 'suszarnia, w jakiej suszy się owoce, len lub konopie' || woznyci(a) 'suszarnia' || wożnycia || tużnycia i wużnycia || waznycia (?) (ważnycia) || łozni(a), łoznyci(a) 'suszarnia na len i konopie' (J), озниия 'сушарня' (Szuchewycz), i bukowińskich, por. лозница 'сушарка для фруктів' (SBH). Oba znaczenia uwzględnia słownik B. Hrinczenki, por. озниця 1. 'дыра на крыше, куда дым выходит'. 2. 'сушильня для сушения садовых овощей, устроенная частью в земле, частью над ней' (Hrincz III: 45). Por. też ESUM (IV: 167). W języku polskim poświadczone od XV w.: ozdnica 'suszarnia słodu na piwo', wtórnie oźnica (XVI-XVII), ozdownia 'suszarnia słodu' (XVI-XVIII) (SEBań II: 472-473), dial. woźnica 'otwór w suficie kurnej chaty do wypuszczania dymu' Mp pd (MSGP: 323), a także oździć 'suszyć słód' (XV-XVII), ózd 'piec do suszenia słodu' (XV) (SEBań II: 475, 478).

- Zapewne polonizm. Pol. ozdnica $<$ oździć, z ps. ${ }^{\star} o z d i t i<{ }^{\star} o z d a, o z d r$ 'piec, suszarnia dla słodu' (ibid.; ESUM IV: 167; ESSJ XXXIX: 240-241).

\section{Окара}

Zapisane ledwie w dwóch źródłach, por. окара 'груба, незграбна людина, неповороткий чоловік' (P1), окара 'неповоротка, незграбна людина' (Р), окара 'coś wielkiego, niezdarnego' $(\mathrm{H})$.

Funkcjonuje u Bojków, por. окара 'дегенерат', także окарятися 'переживати', 'журитися', w gwarach bukowińskich mamy tylko czasownik окарити, вокариmи 'дуже сварити, ганьбити, обзивати' (SBH). ESUM (IV: 168) podaje ponadto: ukr. dial. окар 'щось величезне', окара, огвара, охвара 'тс.', окара 'докір'. W gwarach słowackich: okara expr. 'neprijemná, zlá žena (aj ako nadávka)', okarane 'velmi, strašne, hrozne', okarit' sa 'zbláznit' sa túžbou po niekom al. za niečím' (SSN II: 568), okara 'ohava' (Buffa: 180). Por. też pol. dial. okara przen. 'wszystko, cokolwiek jest 
nieproporcjonalne w częściach, a duże w całości; rzecz wielka a niezgrabna; człowiek albo zwierzę niezgrabne, szpetne, nieudolne, pokraka' (SW III: 729-730).

- ESUM (IV: 168) osobno etymologizuje ukr. dial. окар, окара 'щось величезне', wyprowadzając przez polski z niem. Hochkarre 'wysoka taczka, wysoki wózek', por. pol. okara 'taczka wielka na dwóch kołach; wóz o dwóch kołach wysokich, jak u bidy z nasadem wysokim i z dyszlem, do przewożenia ciężarów' (SW III: 729-730), oraz окара 'дегенерат; докір', co uznaje za pochodne od кара, карати. W drugim przypadku chodzi zapewne o wpływ rum. ocáră 1. 'obelga, zniewaga'. 2. 'wyzwisko'. 3. 'hańba' (WSRP: 569), niewątpliwie o słowiańskiej proweniencji (zob. Oczko: 202).

\section{Окрясти}

Obecne zaledwie w jednym źródle leksykografii łemkowskiej, por. окрясти 'odżyć po deszczu lub podlewaniu (o roślinach), o człowieku, że mu się polepszyło pod względem zdrowia lub samopoczucia', окр'ататіс'а 'остербати, прийти до себе після недуги' (Horb), chyba że zaliczymy tu także окріяти 'поправлятись, приходити до себе' (P1), окрияти 'прийти до звичайного, нормального стану, вигляду (про городні рослини)' (Т).

Widoczne w Słowniku huculskim J. Janowa: okryjaty 'przyść do siebie, wrócić do zdrowia' (J). ESUM (IV: 173) uwzględnia ukr. dial. окріяти 'одужати; поздоровшати', откріяти 'тс.', роwiązane z кріяти 'ставати здоровим, міцним' (ESUM III: 99). W języku i gwarach słowackich: okriat 'znova nadobudnút duš. al. teles. silu, vzpružit' sa, oživnút' (KSSJ: 262), okriat' (okrít) 'duševne al. telesne sa vZpružit, vzchopit sa, oživnút' (obyč. pod vplyvom niekoho al. niečoho)' (SSN II: 596). Por. też czes. okřát 'pokrzepić się, nabrać sił, wrócić do zdrowia; poprawić się, wyzdrowieć' (SCP: 449).

- Z ps. ${ }^{*}$ obkrbjati/*obkrějati, składającego się z przedrostka ob- i czasownika

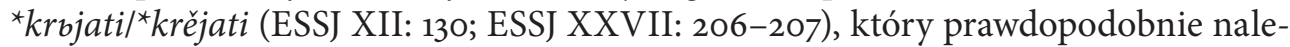
ży wiązać z *krèsiti 'przywracać do życia, ożywiać, cucić' (Králik: 400; SEBor: 713).

\section{Ocyra}

Stosunkowo dobrze udokumentowane w leksykografii, por. osuha '(gnijący) osad na kiszonej kapuście' (R), осуга 'поверхнева плівка, яка утворюється в бочці або іншій посудині з капустою, огірками і т. п.' (B-H; AP), осуга 'osad na gotowanej potrawie lub w beczce na kwasie z kapusty, ogórków itp.' (H), osuha 'pena pri kvasení (napr. kyslej kapusty)' (АН), осуга 'плівка в бочці з квашеною капустою, соленими огірками - osad w beczce z kiszoną kapustą, ogórkami’ (Wys).

Znane w gwarach bojkowskich, por. oсуга 1. 'піна на воді'. 2. 'піна на топленому маслі' (O), huculskich, por. осуга 1. 'плісінь на квашеній капусті'. 2. 'осад (напр., 
в олії)' (НH), i bukowińskich, por. осуга 1. 'плівка, яка утворюється на розсолі квашених огірків, капусти та ін.'. 2. 'наліт на квашених огірках, та ін., залишених на день-два без розсолу' (SBH). W języku ukraińskim cyza, ocyza występuje w dwóch znaczeniach: 1. 'масні або іржаві плями на воді, рідині'. 2. 'наліт на спраглих устах' (WTSSUM: 687; ESUM V: 465). Por. takż brus. dial. acyza, ocyza 'пот; іней, шэрань' (ESBM I: 187), słc. osuhel', osuhlina i osuha (osihel, osucha, ošahel') 1. zried. 'zamrznuté vodné pary, mrznúca hmla; inovat', srieň. 2. 'sivá zimná pleseň na drevených stenách maštale’. 3. 'hnilobný povlak na kapuste v sude’ (SSN II: 656).

- Z ps. ${ }^{*} o b s e g a$ 'to, co osiada', od ${ }^{\star} o b$-sęgti, por. ${ }^{\star}$ sęgti 'sięgać po coś (ESSJ XXX: 23-24; SEBor: 547; Králik: 410). L. Králik rozwój znaczeniowy wyrazu przedstawił następująco: 'siahat' na niečo, natahovat' sa (niekam)' > 'roztahovat' sa po povrchu niečoho' > 'povlak, tenká vrstva na povrchu (o inovati aj plesnach)'. Należy raczej odrzucić pomysł białoruskich etymologów, którzy dopatrują się tutaj derywatu od *osuti 'абсыпаць' (ESBM I: 187).

\section{Отлак}

Posiada nieliczne poświadczenia leksykograficzne, por. otłak 'nagniotek' (R), oтлак 'odcisk' (H).

W języku i gwarach słowackich: otlak 'zrohovatená (bolestivá) pokožka, vzniknutá otlačením (na prstoch nohy), kurie oko' (KSSJ: 273), otlak 1. 'otlačené, ošúchané miesto na pokožke, pluzgier'. 2. 'stvrdnutá, zrohovatená, pokožka' (SSN II: 672). Por. też czes. otlak med. 'odgniecenie' (SCP: 471), pol. dial. (Pomorze pd) otłok 'odcisk' (MSGP: 178).

- Względy fonetyczne $\left(-l a-<p s .{ }^{*}\right.$-ol-) wskazują na zapożyczenie z języka słowackiego. Z ps. ${ }^{*}$ obtolkr ( ${ }^{\star} o b-+{ }^{\star}$ tolkr 'tłoczenie, ścisk, gniecenie; coś stłoczonego, zgniecionego, ugniecionego'), por. “tolčiti 'tłoczyć, ściskać, naciskać, przyciskać, gnieść, czas. wielokrotny od ps. *telkti 'bić, tłuc, gnieść (ESSJ XXX: 189; SEBor: 634). Wyraz rodzimy na „odcisk” to натовканеu - zob. обтавкати.

\section{0ферма zob. уферма}

\section{Skróty}

brus. - białoruski; buk. - bukowiński; cf. - confer (porównaj); czes. - czeski; daw. - dawny; dial. - dialektalny; fr. - francuski; huc. - huculski; kaszub. - kaszubski; lit. - litewski; łac. łaciński; łemk. - łemkowski; med. - medyczny; niem. - niemiecki; perf. - perfectum; pie. praindoeuropejski; płn. - północny; pol. - polski; przen. - przenośnie; ps. - prasłowiański; ros. - rosyjski; rum. - rumuński; sch. - serbsko-chorwacki; słc. - słowacki; ukr. - ukraiński; węg. - węgierski 


\section{Literatura}

A: G. Arkušin, Slovnik zahidnopolis'kih govirok, t. I-II, Luc'k 2000.

AH: A. Hnát, Krátky rusínsky slovník, Trebišov 2003.

AP: A. Pavlešin, Mali rječnik lemkivskog govora ukrajinskog jezika, Zagreb 2007.

BAR: J.A. Rieger, Mały słownik łemkowskiej wsi Bartne, Warszawa 2016.

B-H: A. Bìgunâk, O. Gojsak, Lemkivs'kij slovničok, Ternopil' 1997.

BR: R. Bronikowska, Dawne słownictwo zachodniołemkowskiej gwary Szczawnika koło Krynicy, [w:] J. Rieger (red.), Studia nad słownictwem gwar ukrainskich w Polsce. Łemkowszczyzna i gwary nadsańskie, Warszawa 2002, s. 17-64.

Buffa: F. Buffa, Slovník šarišských nárečí, Prešov 2004.

D: K. Domaradz, Słownictwo wsi Żernica na pograniczu łemkowsko-bojkowskim, [w:] J. Rieger (red.), Studia nad słownictwem gwar ukrainskich w Polsce. Łemkowszczyzna i gwary nadsańskie, Warszawa 2002, s. 65-106.

ESBM: V.U. Martynaǔ (red.), Etymalagičny sloǔnik belaruskaj movy, t. 1-, Mìnsk 1978-.

ESSJ: O.N. Trubačev (red.), Ėtimologičeskij slovar' slavânskih âzykov. Praslavânskij leksičeskij fond, t. 1-, Moskva 1974-.

ESUM: O. Mel'ničuk (red.), Etimologičnij slovnik ukraïns'koï movi, t. 1-6, Kï̈v 1982-2012.

FAL: J. Falkowski, B. Pasznycki, Na pograniczu łemkowsko-bojkowskim. Zarys etnograficzny, Lwów 1935.

FSŁH: H. Stupìns'ka, Â. Bitkìvs'ka, Frazeologičnij slovnik lemkivs'kih govirok, Ternopil' 2013.

H: J. Horoszczak, Słownik łemkowsko-polski, polsko-łemkowski, Warszawa 2004.

HH: Â. Zakrevs'ka (red.), Gucul's'ki govirki. Korotkij slovnik, L'vìv 1997.

Horв: O. Gorbač, Pìdennolemkivs'ka govirka j diâlektnij slovnik sela Krasnij Brìd bl. Medžilaborec' (Prâšivîina), Mûnhen 1973.

Hrincz: B. Grìnčenko (red.), Slovar' ukraïns'koï movi, t. I-IV, Kiïv 1907-1909.

J: J. Janów, Słownik huculski, oprac. i przygot. do druku J. Rieger, Kraków 2001.

Kок: F. Kokovs'kij, Dopovnennâ do lemkivs'kogo slovnička, „Rìdna mova” lûtij 1935, s. 75-76.

KRÁLIK: L. Králik, Stručný etymologický slovník slovenčiny, Bratislava 2015.

KSGP: Kartoteka Słownika gwar polskich, [on-line:] http://rcin.org.pl/publication/37156.

KSSJ: Krátky slovník slovenského jazyka, Bratislava 1989.

L: U. Lewicka, Słownictwo wsi Terka na pograniczu łemkowsko-bojkowskim, [w:] J. Rieger (red.), Studia nad słownictwem gwar ukrainskich w Polsce. Łemkowszczyzna i gwary nadsańskie, Warszawa 2002, s. 107-180.

Маснек: V. Machek, Etymologický slovník jazyka českého, Praha 1968.

Mańczak: W. Mańczak, Polski słownik etymologiczny, Kraków 2017.

MAт: M. Matï̄, Slovnik govirok central'noï Bojkivščini, Kiïv - Sìmferopol' 2013.

MSGP: J. Wronicz (red.), Mały słownik gwar polskich, Kraków 2010.

O: M. Oniškevič, Slovnik bojkivs'kih govirok, t. 1-2, Kiïv 1984.

Oczко: A. Oczko, Rumuńska słowiańszczyzna. Zapożyczenia południowosłowiańskie w języku rumuńskim w XVI i XVII wieku, Kraków 2014.

P: P. Pirtej, Korotkij slovnik lemkivs'kih govirok, İvano-Frankìvs'k 2004.

P1: P. Pirtej, Slovnik lemkivs' koï govirki. Materiali dlâ slovnika, Legnica 2001.

PAnD: S. Panc'o, Materìali do slovnika lemkivskih govirok (diêslivna leksika), cz. I, Ternopìl' 1997.

R: J. Rieger, Słownictwo i nazewnictwo łemkowskie, Warszawa 1995. 
R-Z: E. Rudolf-Ziółkowska, Dawne słownictwo pogranicza łemkowsko-bojkowskiego, [w:]

J. Rieger (red.), Studia nad słownictwem gwar ukrainskich w Polsce. Łemkowszczyzna i gwary nadsańskie, Warszawa 2002, s. 209-322.

S: G. Šilo, Naddnistrâns'kij regìnal'nij slovnik, L'vìv - N'û-Jork 2008.

SAB: İ. Sabadoš, Slovnik zakarpats'koï govirki sela Sokirnicâ Husts'kogo r-nu, Užgorod 2008. SB: Jaskółka, [w:] Słownik [terminów budowlanych], [on-line:] http://www.e-dach.pl/slow nik/jaskolka.

SBH: N. Gujvanûk (red.), Slovnik bukovins'kih govìrok, Černìvcì 2005.

SCP: J. Siatkowski, M. Basaj, Słownik czesko-polski, wyd. 4, Warszawa 2010.

SEBAń: A. Bańkowski, Etymologiczny słownik języka polskiego, t. 1-2, Warszawa 2000.

SEBor: W. Boryś, Słownik etymologiczny języka polskiego, Kraków 2005.

SEBR: A. Brückner, Słownik etymologiczny języka polskiego, Kraków 1927.

SESŁ: F. Sławski, Słownik etymologiczny języka polskiego, t. I-V, Kraków 1952-1982.

Šiš: R. Šišková, Areálová studie slovní zásoby rusínských nářeči východního Slovenska. Diferenční slovník, Praha 2009.

SJP: M. Szymczak (red.), Słownik języka polskiego, t. I-III, Warszawa 1988-1989.

SP: F. Sławski (red.), Słownik prasłowiański, t. I-VIII, Wrocław 1974-2001.

SPXVI: Słownik polszczyzny XVI wieku, t. I-IV, red. komitet redakcyjny, t. V-XVII, red. M.R. Mayenowa, t. XVIII-XXXIV, red. F. Pepłowski, t. XXXV-XXXVI, red. K. Mrowcewicz, P. Potoniec, Wrocław - Warszawa - Kraków 1966-2012.

SSN: I. Ripka (red.), Slovník slovenských náreči, t. I-, Bratislava 1994-.

SW: J. Karłowicz, A.A. Kryński, W. Niedźwiecki (red.), Słownik języka polskiego, t. I-VIII, Warszawa 1900-1927.

SzUCHEwYCZ: V. Šuhevič, Gucul'ščina, cz. II, L'vìv 1901.

T: Ê. Turčin, Slovnik sela Tilič na Lemkivsinini, L'vìv 2011.

TR: M. Trochanowski, Słownik polsko-zachodniołemkowski, Przemyśl 2019.

VASMER: M. Fasmer, Ėtimologičeskij slovar' russkogo âzyka, t. I-IV, Moskva 1986-1987.

W: İ. Verhratskij, Pro govor galickih lemkiv, L'vìv 1902.

WSRP: H. Mirska-Lasota, J. Porawska, Wielki słownik rumuńsko-polski, Kraków 2009.

WTSSUM: V. Busel (red.), Velikij tlumačnij slovnik sučasnoï ukrä̈ns'koï movi, Kï̈v - İrpìn’ 2001.

WU: İ. Verhratskij, Znadobi dlâ piznanâ ugorsko-ruskih govorìv, L’vìv 1901.

WUZ: İ. Verhratskij, Znadobi dlâ piznanâ ugorsko-ruskih govorìv, L'vìv 1899.

Wys: O. Hojsak, Słownik gwary łemkowskiej wsi Wysowa, z materiałów autora oprac. i przygot. do druku M. Aleksiejewa, J. Rieger, Warszawa 2018.

WZ: İ. Verhratskij, Govor zamišanciv, L'vìv 1894.

\section{Lemko Etymologies. Part V Summary}

The present paper is the fifth part in the Lemko etymologies series; analysed in it are words beginning with letters Л, М, Н, О: ластівниия, люштати, лябати, лябдати, лянкорити ся, маляга, маранча, масеса, маскати, мджурити, медера, металеи, микытаня, м(л)юзгра, моликати, мосур, мотлочыти, муиикы, нарабяти, нарубы, нахыр, нездобачкы, непек, ніверити, нозгри/ нозгрі, нютер, обатурити ся, обгартати, обтавкати, одкырхнути ся, одразити, одчезнути, 
озниия, окара, окрясти, осуга, отлак. Authors attempt to establish the origin of those words, taking into account data from etymological, historical, and dialectal dictionaries of Slavic languages and dialects, as well as from the neighbouring non-Slavic languages, thereby outlining a broad comparative background. They propose additions and corrections to previous etymological findings regarding some of the discussed words. 